\title{
Research into the Epipelic Diatoms of the Meriç and Tunca Rivers and the Application of the Biological Diatom Index in Water Quality Assessment
}

\author{
Cem Tokatlı (D), Cüneyd Nadir Solak² (D), Elif Yılmaz² (D), Tahir Atıcı ${ }^{3}$ (D), Hayri Dayıoğlu² (i)
}

Cite this article as: Tokatlı, C., Solak, C. N., Yılmaz, E., Atıcı, T., Dayıoğlu, H. (2020). Research into the epipelic diatoms of the Meriç and Tunca Rivers and the application of the biological diatom index in water quality assessment. Aquatic Sciences and Engineering, 35(1), 19-26.

ORCID IDs of the authors: C.T. 0000-0003-2080-7920; C.N.S. 0000-0003-2334-4271; E.Y. $0000-0002-7814-3429$ T.A. $0000-0002-3396-3407$; H.D. 0000-0002-5233-4024

'Department of Laboratory Technology, Ipsala Vocational School, Trakya University, Edirne, Turkey 2Department of Biology, Dumlupınar University, Kütahya, Turkey ${ }^{3}$ Department of Biology Education, Gazi University, Ankara, Turkey

Submitted: 18.04.2019

Revision Requested: 07.09.2019

Last Revision Received: 16.08.2019

Accepted:

10.10.2019

Online published:

05.12.2019

Correspondence:

Cem Tokatlı

E-mail:

tokatlicem@gmail.com

(C) Copyright 2020 by Aquatic Sciences and Engineering Available online at

https://dergipark.org.tr/ase

\section{ABSTRACT}

The Meriç River is one of the longest rivers of the Balkans and the Tunca River is the most significant tributary of the Meriç River. In the present study, the epipelic diatoms of the Meriç and Tunca Rivers were investigated and the water quality was evaluated from a physicochemical and biological perspective. Epipelic (EPP) diatoms were collected from the middlestream of the Meriç River (Edirne Province of Turkey) and from the downstream of the Tunca River (before emptying into the Meriç River) and certain physicochemical parameters including dissolved oxygen (DO), oxygen saturation (OS), $\mathrm{pH}$, electrical conductivity (EC), total dissolved solids (TDS), salinity, turbidity, nitrate $\left(\mathrm{NO}_{3}\right)$, nitrite $\left(\mathrm{NO}_{2}\right)$, ammonium $\left(\mathrm{NH}_{4}\right)$, phosphate $\left(\mathrm{PO}_{4}\right)$, sulphate $\left(\mathrm{SO}_{4}\right)$, chemical oxygen demand (COD) and oxidation-reduction potential (ORP) were measured during the field studies. The Biological Diatom Index (IBD) was used to determine the trophic status of the Meriç and Tunca Rivers in terms of EPP diatoms, and Cluster Analysis (CA) was applied to the detected biological data in order to classify the identified diatom taxa in terms of their dominance in the system. According to the results of the physicochemical analysis, the Meriç and Tunca Rivers have I. - II. Class water quality in terms of dissolved oxygen, oxygen saturation, $\mathrm{pH}, \mathrm{EC}, \mathrm{TDS}, \mathrm{NO}_{3}, \mathrm{NH}_{4}, \mathrm{SO}_{4}$ and COD parameters; and have III. - IV. Class water quality in terms of $\mathrm{NO}_{2}$ and $\mathrm{PO}_{4}$ parameters. 24 diatom species were recorded in the Meriç River by counting a total of 403 valves and a total of 19 diatom species were identified by counting a total of 409 diatom valves in the Tunca River. Cyclotella atomus Hustedt, Navicula gregaria Donkin, Nitzschia palea (Kützing) W.Smith and Nitzschia subacicularis Hustedt, were determined as the most dominant species in the Meriç River and Navicula erifuga Lange-Bertalot, Navicula gregaria Donkin and Navicula rostellata Kützing were recorded as the most dominant taxa in the Tunca River. According to the result of the IBD, the investigated rivers were found to be in a meso-eutrophic state and according to the results of $\mathrm{CA}$, three statistical clusters were formed for both rivers, and were named as "dominant taxa", "frequent taxa" and "rare taxa".

Keywords: Meriç River, Bentic diatoms, Biological Diatom Index, Cluster Analysis

\section{INTRODUCTION}

Rapid world population growth, a lack of environmental awareness in society and developments in industry have been the cause of significant environmental problems - especially so in the last century. One of the biosphere compo- nents affected most by this pollution is undoubtedly freshwater ecosystems. Therefore monitoring water quality is a necessity for the sustainability and protection of water ecosystem health (Çiçek et al., 2013; Köse et al., 2014; Tokatlı et al., 2016). Using only physical and chemical water quality monitoring methods 
may be inadequate, and especially in recent years, biological monitoring methods and bio-indicator organisms have been widely used in the scientific community for effective research (Martin et al., 2010; Solak and Acs, 2011; Tokatlı and Dayıoğlu, 2011; Delgado et al., 2012; Atıcı and Udoh, 2016).

Diatoms, which are known to be a large part of the benthos (often $90-95 \%)$, can be found in all surface waters all the time. They are also one of the most important aquatic producer groups and have quick reactions to the changes in environmental variables. Therefore, diatoms, which are accepted as an important part of bio-indicator organisms, have been used to evaluate environmental conditions in many countries as indicators of water pollution (Ács et al., 2004; Goma et al., 2004; Atıcı and Obalı, 2006; Solak et al., 2007; Kalyoncu et al., 2009; Atıcı and Obalı, 2010; TokatIı, 2013; Aydın and Büyükışık, 2014; Tan et al., 2017). Diatom indices developed for different conditions in different habitats are one of the most widely used water quality assessment techniques and the Biological Diatom Index (IBD) is one of the most convenient indexes for evaluating the water quality by using diatom communities (Coste et al., 2009).

The Meriç and Tunca Rivers are two of the most significant lotic ecosystems for the Balkans and it is well documented that they are being exposed to intensive anthropogenic pressure - especially from agricultural and domestic applications conducted on their watersheds (Erkmen and Kolankaya, 2006; Tokatlı and Baştatlı, 2016; Tokatlı, 2017). The aim of this study was to determine the epipelic diatoms of selected stations on the Meriç and Tunca Rivers and to evaluate/compare the water quality by using certain limnologic parameters and the Biological Diatom Index (IBD).

\section{MATERIAL AND METHOD}

\section{Study Area}

Water and epipelic (EPP) diatom samples were collected from 2 selected stations on the Meriç and Tunca Rivers in autumn (November) 2018. A map of the study area and the selected stations is shown in Figure 1.

\section{Physical and Chemical Parameters}

The dissolved oxygen, oxygen saturation, $\mathrm{pH}, \mathrm{EC}$, TDS, salinity and oxidation - reduction potential (ORP) parameters were determined using a Hach Lange branded "HQ40D Multiparameter" device during the field studies; the turbidity parameter was determined using a Hach Lange branded "21000 Portable Turbiditymeter" device during the field studies; the nitrate, nitrite, ammonium, phosphate, sulphate and chemical oxygen demand (COD) parameters were determined using a Hach Lange branded "DR3900 Spectrophotometer" device during the laboratory studies.

\section{Epipelic (EPP) Diatoms}

A glass pipe with a diameter of $0.8 \mathrm{~cm}$ and $100-150 \mathrm{~cm}$ long was used for capturing EPP diatom samples. Then the diatom samples collected from the field were cleaned with acid $\left(98 \% \mathrm{H}_{2} \mathrm{SO}_{4}\right.$ and $35 \% \mathrm{HNO}_{3}$ ) and mounted on a microscope for observation at a magnification of 1000X. Slides were prepared and approximately 400 valves were enumerated on each slide to determine the relation and abundance of each taxa (Sladecova, 1962; Round, 1993). Diatoms were identified according to Cox (1996) and Krammer and Lange-Bertalot (1986; 1988; 1991a; 1991b).

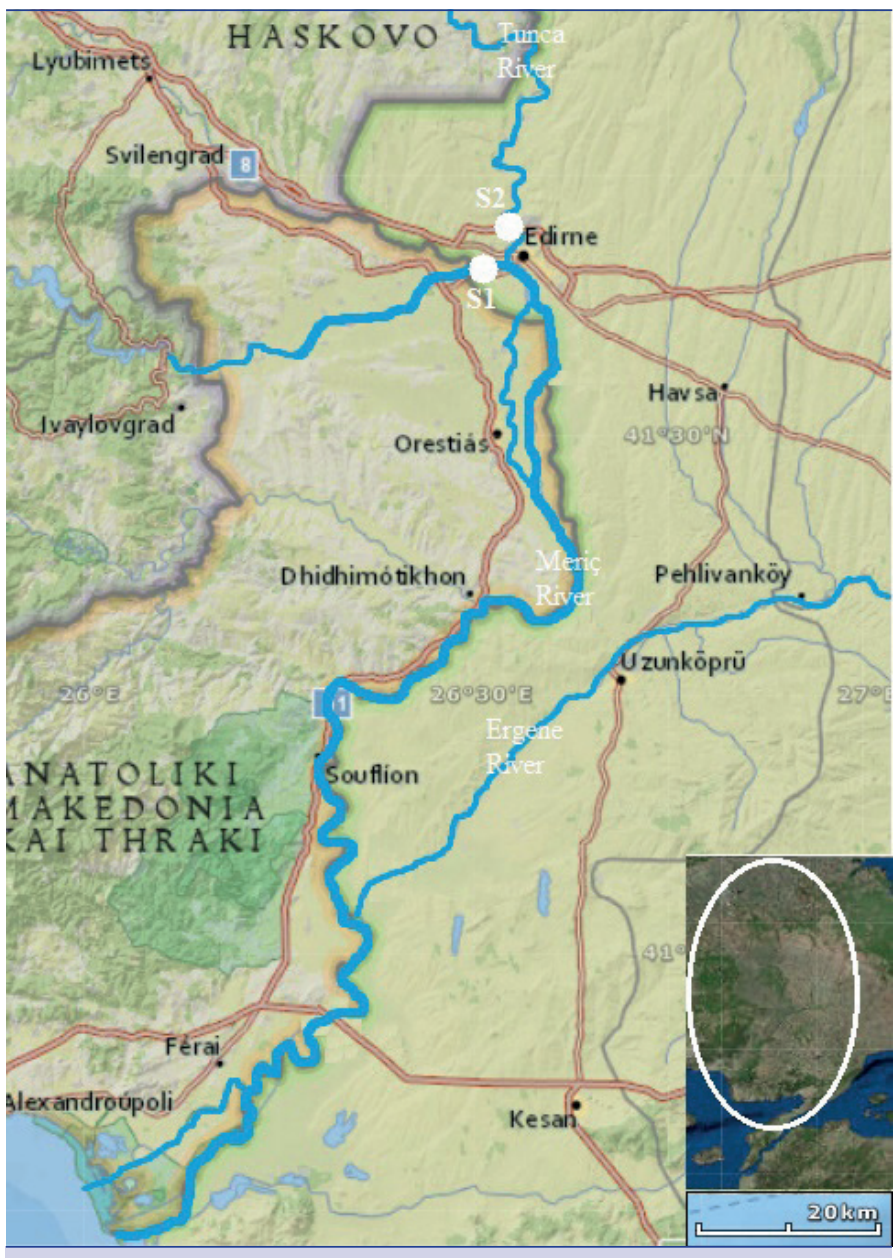

Figure 1. The Meriç River Basin and the selected stations.

\section{The Biological Diatom Index (IBD)}

The Biological Diatom Index (IBD) values of the Meriç and Tunca Rivers were automatically calculated using the "Calculate IBD with Excel" program. The trophic statuses and quality classes of freshwater according to IBD values are given in Table 1 (Lenoir and Coste, 1996).

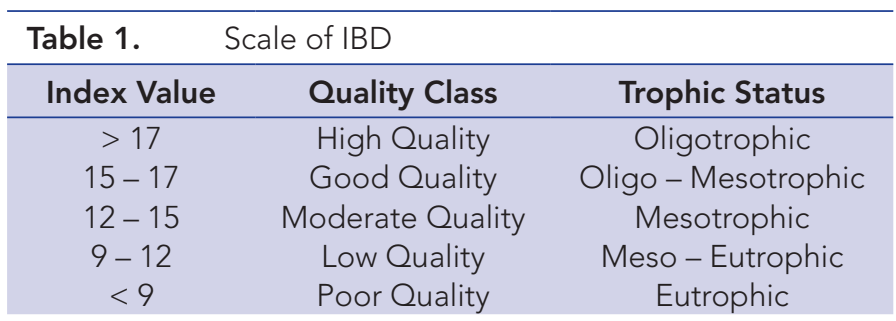

\section{Statistical Data}

Cluster Analysis (CA) according to Bray Curtis was applied to the results using the "Past" package program in order to classify the diatom species in terms of their relative abundances. 


\section{RESULTS AND DISCUSSION}

\section{Physical and Chemical Data}

The results of the physicochemical data detected in the 2 stations selected on the Meriç and Tunca Rivers and some nationalinternational limit values are given in Table 2. According to the criteria of the Water Pollution Control Regulations in Turkey, the Meriç and Tunca Rivers have I. - II. Class water quality in terms of dissolved oxygen, oxygen saturation, $\mathrm{pH}, \mathrm{EC}$, TDS, nitrate, ammonium, sulphate and COD parameters; and have III. - IV. Class water quality in terms of nitrite and phosphate parameters (Uslu and Türkman, 1987; Turkish Regulations, 2015).

Nitrite is known as an intermediate product in the biological oxidation process reaching from ammonium to nitrate. It may reach high concentrations in low-oxygen and in especially organically contaminated water. It is also known that organic and inorganic fertilizers, municipal and industrial wastewater discharges are the most important factors in increasing the amount of ammonia and phosphate in water (Wetzel, 2001; Manahan, 2011). Özkan and Elipek (2006) investigated the water quality of the Meriç River using certain physicochemical parameters. As a result of this research, the Meriç River was reported as having II. Class water quality level in terms of phosphate, II - III. Class water quality level in terms of nitrate, and III - IV. Class water quality level in terms of nitrite. In a study performed in the same basin, and similar to the present study, the Meriç, Tunca and Ergene Rivers were reported as III. - IV. Class in terms of nitrite, ammonium and phosphate accumulations in water (Tokatlı, 2015). In another study performed in the Meriç-Ergene River Basin, the water and sediment qualities of the basin components were investigated. According to the results of this research, and similar to the present study, the Meriç River Basin was found to have I. - II. Class water quality in terms of temperature, DO, COD, pH, TDS, nitrate, ammonium and sulphate parameters; II. Class water quality in terms of nitrite parameters; and III. - IV. Class water quality in terms of phosphate, BOD and fecal coliform parameters in general (Tokatlı, 2019). According to the DSI observation reports, nitrogen and phosphorus are the main concerns affecting the water quality of Meric River (Kendirli et al., 2005). Similar to the data reported by the DSI, the nitrite and phosphate concentrations in the water from the Meriç and Tunca Rivers were detected in quite high levels and they have III. - IV. Class water quality in terms of these parameters.

\section{Biological Data}

During the present study, a total of 36 diatom species were identified from the epipelic (EPP) habitats of the Meriç and Tunca rivers by counting a total of 403 valves in the Meriç and 409 valves in the Tunca. A list of identified diatom taxa with the frequency values of the investigated stations is given in Table 3 and the rel-

Table 2. Results of detected parameters and some national-international limit values

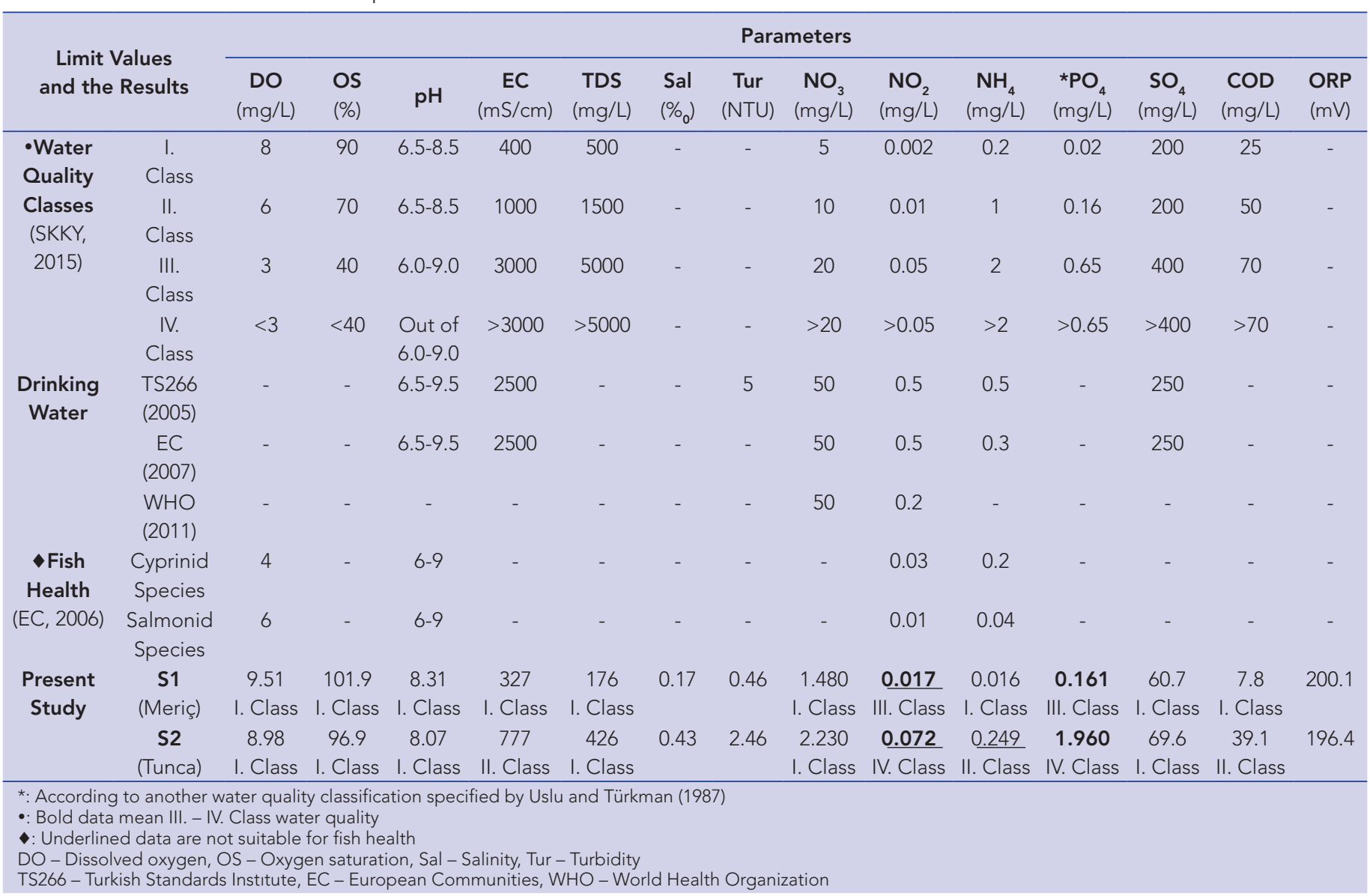


Table 3. Identified diatom taxa

\begin{tabular}{|c|c|c|}
\hline Diatom Taxa & Tunca River & Meriç River \\
\hline Amphora pediculus (Kützing) Grunow & + & + \\
\hline Bacillaria paxillifera (O.F.Müller) T.Marsson & + & - \\
\hline Cocconeis pediculus Ehrenberg & + & - \\
\hline Craticula subminuscula (Manguin) Wetzel \& Ector & - & + \\
\hline Cyclotella atomus Hustedt & - & + \\
\hline Cyclotella meneghiniana Kützing & - & + \\
\hline Cymbella tumida (Brébisson) Van Heurck & + & - \\
\hline Diatoma vulgaris Bory & - & + \\
\hline Encyonema minutum (Hilse) D.G.Mann & - & + \\
\hline Frustulia vulgaris (Thwaites) De Toni & + & + \\
\hline Geissleria decussis (Østrup) Lange-Bertalot \& Metzeltin & - & + \\
\hline Gyrosigma kuetzingii (Grunow) Cleve & + & - \\
\hline Melosira varians C.Agardh & + & + \\
\hline Navicula amphiceropsis Lange-Bertalot \& U.Rumrich & - & + \\
\hline Navicula capitatoradiata H.Germain ex Gasse & - & + \\
\hline Navicula erifuga Lange-Bertalot & + & + \\
\hline Navicula germainii J.H.Wallace & + & - \\
\hline Navicula gregaria Donkin & + & + \\
\hline Navicula perminuta Grunow & - & + \\
\hline Navicula radiosa Kützing & - & + \\
\hline Navicula recens (Lange-Bertalot) Lange-Bertalot & + & - \\
\hline Navicula rostellata Kützing & + & + \\
\hline Navicula simulata Manguin & + & \\
\hline Nitzschia amphibia Grunow & - & + \\
\hline Nitzschia clausii Hantzsch & + & - \\
\hline Nitzschia dissipata (Kützing) Rabenhorst & - & + \\
\hline Nitzschia dubia W.Smith & + & - \\
\hline Nitzschia inconspicua Grunow & + & - \\
\hline Nitzschia linearis W.Smith & - & + \\
\hline Nitzschia palea (Kützing) W.Smith & + & + \\
\hline Nitzschia sociabilis Hustedt & - & + \\
\hline Nitzschia subacicularis Hustedt. nom. inval. & - & + \\
\hline Pantocsekiella ocellata (Pantocsek) K.T.Kiss \& Ács & - & + \\
\hline Reimeria sinuata (W.Gregory) Kociolek \& Stoermer & - & + \\
\hline Stephanodiscus hantzschii Grunow & + & - \\
\hline Tryblionella calida (Grunow) D.G.Mann & + & - \\
\hline
\end{tabular}

ative abundance values of the detected EPP diatom species, which have relative abundance values higher than $1 \%$ for the Meriç and Tunca Rivers, are given in Figure 2. Cyclotella atomus Hustedt, Navicula gregaria Donkin, Nitzschia palea (Kützing) W. Smith and Nitzschia subacicularis Hustedt, nom. inval. were found as the most dominant species in the Meriç River and Navicula erifuga Lange-Bertalot, Navicula gregaria Donkin and Navicula rostellata Kützing were found as the most dominant taxa in the Tunca River.

Navicula rostellata, which is found as the most dominant taxon (relative abundance of 50\%) for the Tunca River, is a cosmopolitan eutrophic species. Navicula erifuga, which is found as the second most dominant taxon (relative abundance of $25 \%$ ) for the
Tunca River, is a cosmopolitan species found in eutrophic, brackish waters or those with very high electrolyte content. Both species with very high abundance values in the Tunca River are tolerant to critical levels of pollution (Taylor et al., 2007). Navicula gregaria, which is found as the most dominant taxon (relative abundance of 52\%) in the Meriç River, is a cosmopolitan species. It is very common in eutrophic to hypertrophic freshwaters with a moderate to high electrolyte content. N. gregaria tolerant of strongly polluted conditions may also be found in brackish waters. It is also known as a good indicator species for these conditions. Cyclotella atomus, which is found as the second most dominant taxon (relative abundance of 12\%) in the Meriç River, occurs in the electrolyte rich waters (Taylor et al., 2007). 

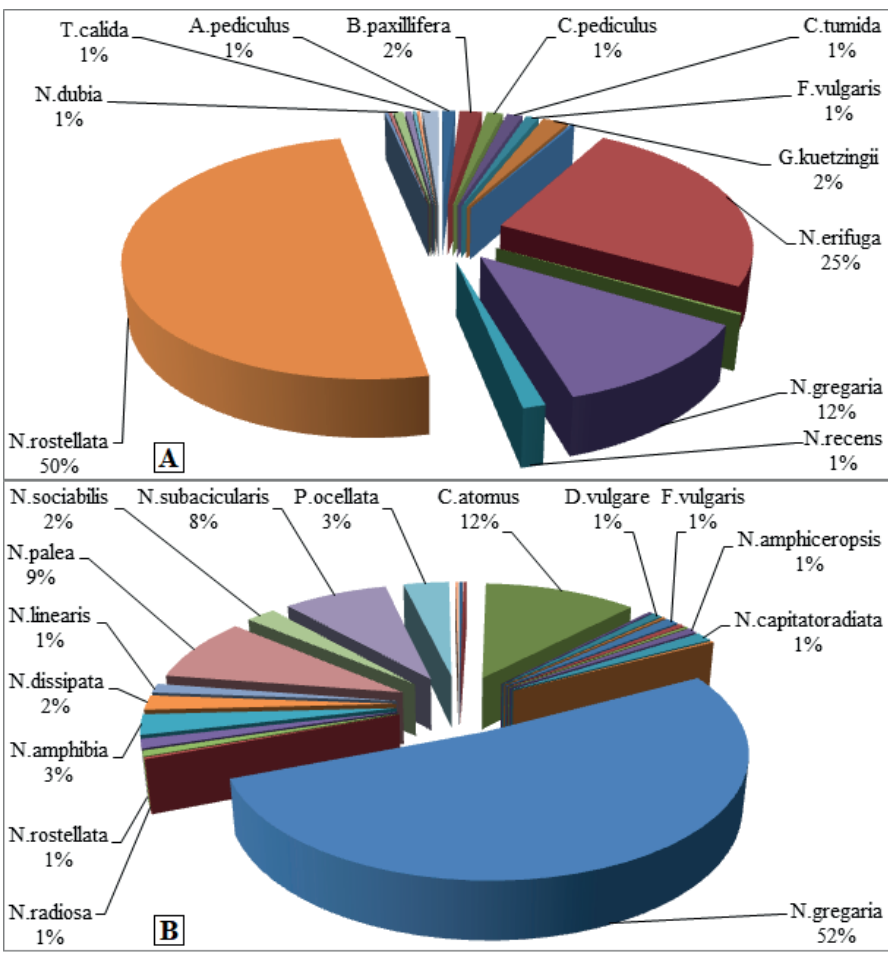

Figure 2. Relative abundance of diatoms in Tunca $(A)$ and Meriç (B) rivers.

\section{Cluster Analysis (CA)}

Cluster Analysis (CA), which classifies the objects, is one of widely used multivariate statistical techniques and hierarchical agglomerative clustering is the most common approach in CA applications (Shrestha and Kazama, 2007; Kazi et al., 2009; Tokatlı et al., 2014). In the present study, CA was applied to the results in order to classify the EPP diatoms of the Meriç and Tunca Rivers according to their relative abundance values. According to the results of CA, three statistically significant clusters were formed both for the diatoms of the Meriç and Tunca Rivers and these detected clusters were named as "dominant taxa", "frequent taxa" and "rare taxa" (Figure 3).

It is known that the Meriç River, which is one of the largest rivers flowing on Europa territory, is a transboundary fluvial ecosystem. Therefore the quality of its waters is of substantial importance for irrigation, industrial, recreation and domestic use for Bulgaria, Greece and Turkey and the control-management of the Meriç catchment is of mutual interest for the neighboring countries. In a study performed in the upstream of the Meriç River Basin, Cluster Analysis (CA) was applied for a model assessment of the water quality of the Meriç River on Bulgarian territory using longterm monitoring data from 21 sampling sites characterized by 8 surface water quality indicators. The application of CA to the indicators resulted in 3 significant clusters showing the impact of biological, anthropogenic and eutrophication sources and the results identified the dominant role of the industrial wastes and agricultural activities in water pollution (Papazova and Simeonova, 2013).
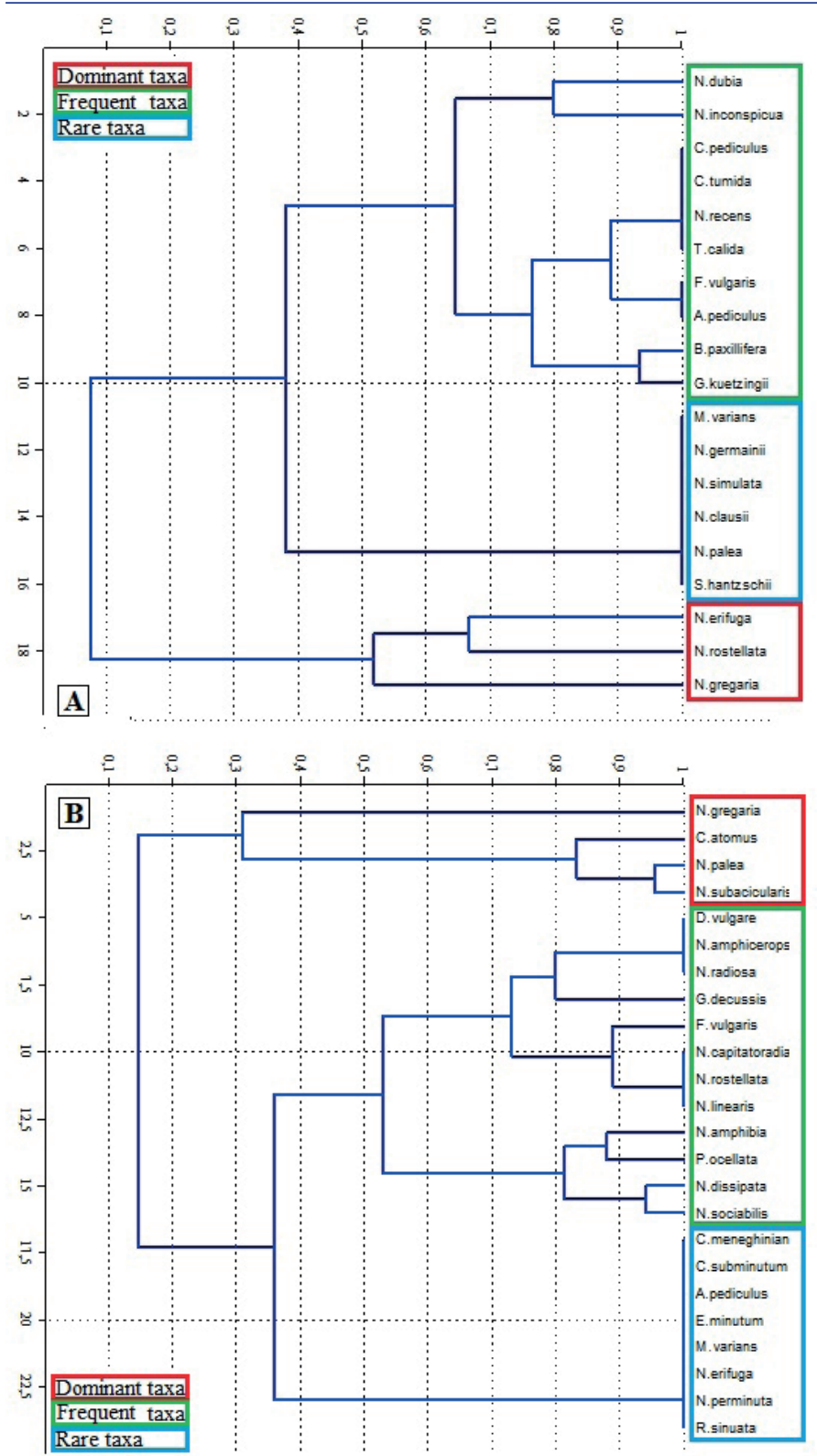

Figure 3. Tree dendrograms of CA for Tunca (A) and Meriç (B) Rivers.

\section{The Biological Diatom Index (IBD)}

The Biological Diatom Index (BDI) is a standardized biologically water quality assessment method. The BDI, the formula of which was developed by Zelinka and Marvan (1961), is based on a total of 209 diatom taxa and provides information about trophic levels of the investigated aquatic ecosystems (Coste et al., 2009). In the present study, a total of 36 diatom taxa were identified and 34 of them were used to calculate the Biological Diatom Index (BDI) scores of the Meriç and Tunca Rivers in order to determine the trophic statuses. The BDI index values of the investigated rivers are given in Figure 4. According to the calculated BDI values for the EPP habitats of the investigated aquatic ecosystems, the Meriç and Tunca Rivers were in "meso - eutrophic state" and had "low water quality" (score range of 9-12) in general. 


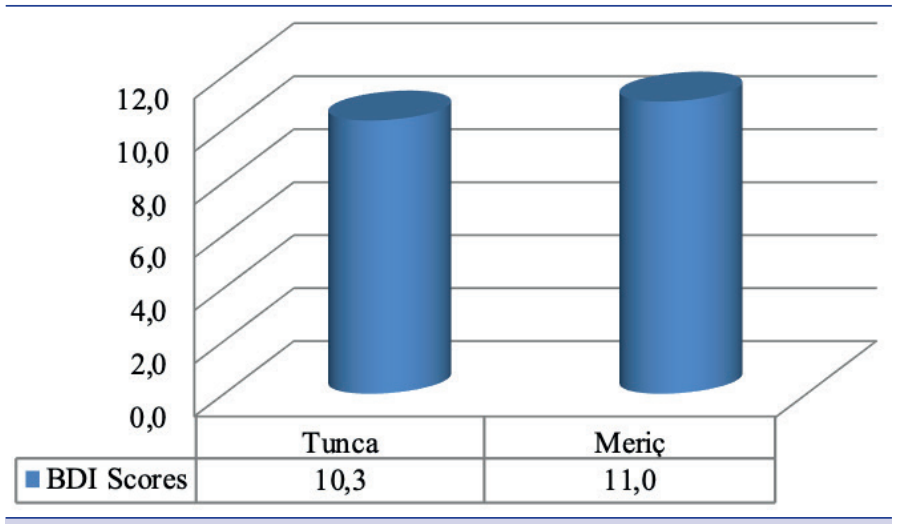

Figure 4. BDI scores of Tunca and Meriç Rivers.

The physicochemical parameters used to assess the water quality may only indicate the current status of aquatic habitat. But the diatoms, which should be used in monitoring programs of rivers ecological assessment according to the Water Framework Directive (WFD), may indicate the long term changes in aquatic ecosystems. Therefore they have been widely used for the bio-assessment of lotic and lentic ecosystems for a long time in almost all the countries of Europe due to their broad distribution and their ability to integrate changes occurring in water composition (Acs et al., 2004; Torissi and Dell'Uomo, 2006; Solak and Acs, 2011).

Diatom indices are widely used worldwide to determine the quality and trophic levels of aquatic systems. In a study performed in Portugal, the water qualities of the Caiman and Mau River Basins were evaluated using the Specific Pollution Index (SPI) and the Biological Diatom Index (BDI). According to the results of this research, the water and diatom data showed a medium to good water quality. However, samples collected near the mining areas (Coval da Mó) revealed a low abundance and diversity of diatom taxa indicating a stressed environment (Nunes et al., 2003). In another study performed in Poland, the Biological Diatom Index (BDI) was used for the estimation of water quality in the central section of the Pilica River, located in Łódź province. As a result of this study, the ecological state of the Pilica River changed from good (oligo - mesotrophic) to moderate (mesotrophic), which corresponded with the physicochemical analysis of the water (Szulc and Szulc, 2013). Pham (2017) used the Biological Diatom Index (BDI) to evaluate the water quality of the Dong Nai River (Vietnam). As a result of this study, similar to the present study, the water quality of the investigated river varied from good (oligo mesotrophic), moderate (mesotrophic), to low (meso - eutrophic) levels, based on the BDI values. Although water quality assessment using diatom indices has been used worldwide for many years, several studies have been also been carried out in Turkey especially in the last 15 - 20 years. Gürbüz and Kıvrak (2002) were applied saprobity index (SI), trophic diatom index (TDI) and the percentage pollution tolerant valves in order to assess the water quality of Karasu River and they found that the Karasu River were eutrophicated and organically polluted. Kalyoncu et al. (2009) investigated the Darı̈ren Stream by ecological methodologies to evaluate the impact of the pollution on epilithic diatom assemblages. SLA, EPI-D, TDI and DESCY indices were used by Solak
(2011) in Upper Porsuk River (Kütahya) and according to the results of this study, the water quality levels of the investigated stations were found in different trophic conditions.

In this study, the Biological Diatom Index (IBD) was used to assess the water quality of the Meriç and Tunca Rivers and this data was compared with the limnological parameters data. Similar to the resulting limnological data, the Meriç and Tunca Rivers were found to be in a "meso-eutrophic state" and had "low water quality" in terms of the calculated IBD values. In a number of studies performed in the Gürleyik, Ankara and Seydisuyu Streams (Central Anatolian Region of Turkey), the IBD was used to evaluate the water quality of these lotic ecosystems. According to the results of these studies, and in line with the investigated physicochemical data, the Gürleyik, Ankara and Seydisuyu Streams were found to be in a mesotrophic state (Tokatlı, 2012, Atici ve Ahiska, 2005; Atıcı et al., 2018). In the present study, the detected similarities in water quality status between the results of the IBD scores and the limnological parameters indicate that the IBD may be used to reflect changes in ecological conditions of the basin potentially after making some revisions in the index.

\section{CONCLUSION}

Biological water quality assessment is much more effective (especially in the long term) in reflecting any effects on water ecosystems than investigated psychochemical data. Therefore any limnological data has to be supported by biological data to make a much better assessment. In this study, the epipelic diatoms of the Meriç and Tunca Rivers were investigated and the water quality of these fluvial ecosystems were evaluated using the Biological Diatom Index. As a result of this study, it was determined that the Meriç and Tunca Rivers have I. - II. Class water quality in terms of dissolved oxygen, oxygen saturation, $\mathrm{pH}, \mathrm{EC}$, TDS, $\mathrm{NO}_{3}, \mathrm{NH}_{4}, \mathrm{SO}_{4}$ and COD parameters; and have III. - IV. Class water quality in terms of $\mathrm{NO}_{2}$ and $\mathrm{PO}_{4}$ parameters and the water of these rivers is in a meso-eutrophic state according to the results of the IBD. It was also determined that the biologically determined water qualities of the rivers showed a high similarity with the physico-chemically determined water qualities - especially in terms of nitrogen and phosphorous compounds. The results of this study also showed the benefits of using biotic and abiotic factors together in water quality assessment studies and show that minor changes in environmental conditions may cause major effects in the diatom communities. While the sampling frequency is perhaps not sufficient and more research is needed for the assessment of quality status of the investigated water ecosystems, the results of the present study do have the characteristics of a preliminary research with the aim of providing resources for any future bio-indication studies in the region.

Financial Disclosure: The present study was funded by the Trakya University, Commission of Scientific Research Projects (Project No. 2018/154).

Ethics committee approval: Ethics committee approval is not required.

Conflict of Interest: The authors have no conflicts of interest to declare. 


\section{REFERENCES}

Ács, É., Szabó, K., Tóth, B., Kiss, K. T. (2004). Investıgatıon of benthıc algal communities, especially diatoms of some Hungarian streams in connection with reference conditions of the water framework directives. Acta Botanica Hungarica, 46(3-4), 255-277. [CrossRef]

Atici, T., Ahiska, S. (2005). Pollution and Algae of Ankara Stream. Gazi University Journal of Science, 18.

Atici, T., Obali, O. (2006). Seasonal Variation of Phytoplankton and Value of Chlorophyll a in the Sarıyar Dam Reservoir (Ankara, Turkey). Turkish Journal of Botany, 30, 349-357.

Atici, T., Obali, O. (2010). The diatoms of Asartepe Dam Lake (Ankara), with environmental and some physicochemical properties. Turkish Journal of Botany, 34, 541-548.

Atıcı, T., Tokatlı, C., Çiçek, A. (2018). Diatoms of Seydisuyu Stream Basin (Turkey) and Assessment of Water Quality by Statistical and Biological Approaches. Sigma Journal of Engineering and Natural Sciences, 36(1), 271-288.

Atici, T., Udoh, A. (2016). Indicator Algae of Adrasan Stream (Antalya) Turkey. Sinop Üniversitesi Fen Bilimleri Dergisi, 1, 140-154.

Aydın, G. Ş., Büyükışık, B. (2014). Effects on The Species Specific Variables Nutrient Pulses: Thalassiosira allenii (Takano). Journal of Tekirdag Agricultural Faculty, 11(3), 82-90.

Coste, M., Boutry, S., Tison-Rosebery, J., Delmas, F. (2009). Improvements of the Biological Diatom Index (BDI): Description and efficiency of the new version (BDI-2006). Ecological Indicators, 9, 621-650. [CrossRef]

Cox, E. J. (1996). Identification of Freswater Diatoms from Live Material. Chapman \& Hall. First Edition, 158 pp.

Çiçek, A., Bakiş, R., Uğurluoğlu, A., Köse, E., Tokatlı, C. (2013). The Effects of Large Borate Deposits on Groundwater Quality of Seydisuyu Basin (Turkey). Polish Journal of Environmental Studies, 22(4), 1031-1037.

Delgado, C., Pardo, I., García, L. (2012). Diatom communities as indicators of ecological status in Mediterranean temporary streams (Balearic Islands, Spain). Ecological Indicators, 15, 131-139. [CrossRef]

EC (European Communities) (2006). EC of the European Parliament and of the council of 6 September 2006 on the quality of fresh waters needing protection or improvement in order to support fish life. Directive 2006/44

EC (European Communities) (2007). European Communities (drinking water) (no. 2), Regulations 2007, S.I. No. 278 of 2007.

Erkmen, B., Kolankaya, D. (2006). Determination of organochlorine pesticide residues in water, sediment, and fish samples from the Meriç Delta, Turkey. International Journal of Environmental Analytical Chemistry, 86(1-2), 161-169. [CrossRef]

Gomà, J., Ortiz, R., Cambra, J., Ector, L. (2004). Water quality evaluation in Catalonian Mediterranean Rivers using epilithic diatoms as bioindicators. Vie Milieu, 54, 81-90.

Gürbüz, H., Kivrak, E. (2002). Use of epilithic diatoms to evaluate water quality in the Karasu River of Turkey. Journal of Environmental Biology, 23(3), 239-246

Kalyoncu, H., Çiçek, N. L., Akköz, C., Yorulmaz, B. (2009). Comparative performance of diatom indices in aquatic pollution assessment. African Journal of Agricultural Research, 4(10), 1032-1040.

Kazi, T. G., Arain, M. B., Jamali, M. K., Jalbani, N., Afridi, H. I., Sarfraz, R. A., Baig, J. A., Shah, A. Q. (2009). Assessment of water quality of polluted lake using multivariate statistical techniques: A case study. Ecotoxicology and Environmental Safety, 72, 301-309. [CrossRef]

Kendirli, B., Çakmak, B., Gökalp, Z. (2005). Assessment of Water Quality Management in Turkey, Water International, 30(4), 446-455. [CrossRef]

Köse, E., Tokatlı, C., Çiçek, A. (2014). Monitoring Stream Water Quality: A Statistical Evaluation. Polish Journal of Environmental Studies, 23(5), 1637-1647.
Krammer, K., Lange-Bertalot, H. (1986). Bacillariophyceae. 1. Teil: Naviculaceae. Süßwasser von mitteleuropa, Gustav Fischer Verlag, Band 2-1, Stuttgart.

Krammer, K., Lange-Bertalot, H. (1988). Bacillariophyceae. 2. Teil: Bacillariophyceae, Epithemiaceae, Surirellaceae. Süßwasser von mitteleuropa, Gustav Fischer Verlag, Band 2-2, Stuttgart.

Krammer, K., Lange-Bertalot, H. (1991a). Bacillariophyceae. 3. Teil: Centrales, Fragilariaceae, Eunotiaceae. Süßwasser von mitteleuropa, Gustav Fischer Verlag, Band 2-3, Stuttgart.

Krammer, K., Lange-Bertalot, H. (1991b). Bacillariophyceae. 4. Teil: Achnantheceae, Kritische Ergänzungen zu Navicula (Lincolatae) und Gomphonema, Cesamptliteraturverzeichnis. Süßwasser von mitteleuropa. Gustav Fischer Verlag, Band 2-4, Stuttgart.

Lenoir, A., Coste, M. (1996). Development of a practical diatom index of overall water quality applicable to the French national water board network. In: B.A. Whitton and E. Rott (Eds.), Use of Algae for Monitoring Rivers II. Institut fur Botanik. Univ. Innsbruck 29-43.

Manahan, S. E. (2011). Water Chemistry: Green Science and Technology of Nature's Most Renewable Resource. Taylor \& Francis Group, CRC Press, 398 pages. [CrossRef]

Martín, G., Toja, J., Sala, S. E., Fernández, M. R., Reyes, I., Casco, M. A. (2010). Application of diatom biotic indices in the Guadalquivir River Basin, a Mediterranean basin. Which one is the most appropriated? Environmental Monitoring and Assessment, 170, 519-534. [CrossRef]

Nunes, M. L., Ferreira Da Silva, E., De Almeida, S. F. P. (2003). Assessment of water quality in the Caima and Mau River Basins (Portugal) using geochemical and biological indices. Water, Air, and Soil Pollution, 149, 227-250. [CrossRef]

Ozkan, N., Camur-Elipek, B. (2006). The dynamics of Chironomidae larvae (Diptera) and the water quality in Meric River (Edirne/Turkey). Tiscia, 35, 49-54.

Papazova, P., Simeonova, P. (2013). Environmetric data interpretation to assess the water quality of Maritsa River catchment. Journal of Environmental Science and Health, 48(8), 963-972. [CrossRef]

Pham, T.L. (2017). Comparison between Water Quality Index (WOl) and biological indices, based on planktonic diatom for water quality assessment in the Dong Nai River, Vietnam. Pollution, 3(2), 311-323.

Round, F. E. (1993). A Reviev and Methods for The Use of Epilithic Diatoms for Detecting and Monitorin Changes in River Water Quality, HMSO, London.

Shrestha, S., Kazama, F. (2007). Assessment of surface water quality using multivariate statistical techniques: A case study of the Fuji river basin; Japan. Environmental Modelling \& Software, 22, 464-475. [CrossRef] Sladeckova, A. (1962). Limnological investigation methods for periphyton (Aufwusch) community. Botanical Review, 28, 286-350. [CrossRef]

Solak, C. N. (2011). The application of diatom indices in the Upper Porsuk River, Kütahya - Turkey. Turkish Journal of Fisheries and Aquatic Sciences, 11(1), 31-36. [CrossRef]

Solak, C. N., Fehér, G., Barlas, M., Pabuçcu, K. (2007). Use of epilithic diatoms to evaluate water quality of Akçay Stream (Büyük Menderes River) in Mugla/Turkey. Large Rivers, 17, 327-338. [CrossRef]

Solak, C. N., Acs, E. (2011). Water Quality Monitoring in European and Turkish Rivers Using Diatoms. Turkish Journal of Fisheries and Aquatic Sciences, 11, 329-337. [CrossRef]

Szulc, B., Szulc, K. (2013). The use of the Biological Diatom Index (BDI) for the assessment of water quality in the Pilica River, Poland. Oceanological and Hydrobiological Studies, 42(2), 188-194. [CrossRef]

Tan, X., Zhang, Q., Burford, M. A., Sheldon, F., Bunn, S. E. (2017). Benthic Diatom Based Indices for Water Quality Assessment in Two Subtropical Streams. Frontiers in Microbiology, 8, 601. [CrossRef]

Taylor, J. C., Harding, W. R., Archibald, C. G. M. (2007). An illustrated guide to some common diatom species from South Africa. Report to the water research commission. 
Tokatlı, C. (2012). Sucul Sistemlerin İzlenmesinde Bazı Diyatome Indekslerinin Kullanılması: Gürleyik Çayı Örneği (Eskişehir). Dumlupınar Üniversitesi Fen Bilimleri Enstitüsü Dergisi, 29, 19-26.

Tokatlı, C. (2013). Evaulation of Water Quality by Using Trophic Diatom Index: Exaple of Porsuk Dam Lake. Journal of Applied Biological Sciences, 7, 1-4.

Tokatlı, C. (2015). Assessment of the Water Quality in the Meriç River: As an Element of the Ecosystem in the Thrace Region of Turkey. Polish Journal of Environmental Studies, 24(5), 2205-2211. [CrossRef]

Tokatlı, C. (2019). Water and Sediment quality assessment of the lifeblood of Thrace Region (Turkey): Meriç River Basin. Fresenius Environmental Bulletin, 28(5), 4131-4140.

Tokatlı, C., Baştatlı, Y. (2016). Trace and Toxic Element Levels in River Sediments. Polish Journal of Environmental Studies, 25(4), 17151720. [CrossRef]

Tokatlı, C., Dayıoğlu, H. (2011). Use of Epilithic Diatoms to Evaluate Water Quality of Murat Stream (Sakarya River Basin, Kütahya): Different Saprobity Levels and $\mathrm{pH}$ Status. Journal of Applied Biological Sciences, 5(2), 55-60.

Tokatlı, C., Köse, E., Çiçek, A. (2014). Assessment of the Effects of Large Borate Deposits on Surface Water Quality by Multi Statistical Approaches: A Case Study of the Seydisuyu Stream (Turkey). Polish Journal of Environmental Studies, 23(5), 1741-1751.

Tokatı, C., Köse, E., Arslan, N., Çiçek, A., Emiroğlu, Ö., Dayığlu, H. (2016). Ecosystem Quality Assessment of an Aquatic Habitat in a Globally Important Boron Reserve: Emet Stream Basin (Turkey). International Journal of Environment and Pollution, 59(2/3/4):116-141. [CrossRef]
Tokatlı, C. (2017). Bio - Ecological and Statistical Risk Assessment of Toxic Metals in Sediments of a Worldwide Important Wetland: Gala Lake National Park (Turkey). Archives of Environmental Protection, 43(1), 34-47. [CrossRef]

Torrisi, M., Dell'uomo, A. (2006). Biological monitoring of some Apennine rivers (Central Italy) using the diatom-based Eutrophication/Pollution Index (EPI-D) compared to other European diatom indices. Diatom Research, 21, 159-174. [CrossRef]

TS 266 (2005). Sular-Insani tüketim amaçlı sular. Türk Standartları Enstitüsü, ICS 13.060.20.

Turkish Regulations, 2015. Yüzeysel Su Kalitesi Yönetimi Yönetmeliği, 15 Nisan 2015 tarihli Resmi Gazete, Sayı: 29327.

Uslu, O., Türkman, A. (1987). Su Kirliliği ve Kontrolü. T.C. Başbakanlık Çevre Genel Müdürlüğü Yayınları, Eğitim Dizisi I, Ankara.

Wetzel, R. G. (2001). Limnology: Lake and River Ecosystems. Elsevier Academic Press, 1006 pages.

WHO (World Health Organization) (2011). Guidelines for Drinking-water Quality. World Health Organization Library Cataloguing-inPublication Data, NLM classification: WA 675.

Zelinka, M., Marvan, P. (1961). Zur Präzisierung der biologischen klassifikation der Reinheit fließender Gewässer. Archiv für Hydrobiologie, 57, 389-407. 